\title{
Cultural Heritage Use in the Twenty-first Century: The Politics of a Sami Skeleton Reburial
}

In the spring of 2009 , the director of the county museum Jamtli and I met with Ingwar Åhrén from the Sami village of Ohredahke. The meeting was held in the museum's café, and the reason we met was that Ingwar wanted to discuss the possibility of reburying a Sami skeleton. The skeleton, which was part of Jamtli's collection, had been found in 1984 in a damaged grave on a cliff by Lake Gransjön in Frostvikenfjällen, northern Jämtland. The stones covering the grave had fallen off in different directions, and parts of the skeleton and grave goods were almost completely exposed. The grave was inspected by Jamtli and representatives of the County Administration of Jämtland in the following year, whereupon it was concluded that an archaeological investigation was necessary. The Sami villages in Jämtland were informed of the plans, and in 1986 the grave was investigated. The excavation results were published (Sundström I988) but after that the find faded into anonymity in a storage room in the museum.

Reburial of an archaeologically investigated (Sami) material is very unusual. It has only happened once before in Sami territory. This was when a grave at Atoklinten in Västerbotten County was restored to its original condition 52 years after being excavated. The reburial did not trigger any special discussion because the excavator of the grave, Ernst Manker from Nordiska museet, had at the time of investigation left a written guarantee that the skeleton would be reburied. The reburial at Atoklinten was also the first in all of Sweden. In the case of Lake Gransjön, however, the situation was different. There were no earlier promises of reburial, and neither did anyone know who had lain in the grave, other than that it was a Sami woman who had died sometime around the year 1500 . For us at Jamtli, and for those at the County Administration of Jämtland, it was fairly easy to take a positive stance to the wishes of the Sami village. There were several reasons for this, but the main one was that it was important for the Sami village. Reburial of the skeleton 
took place in the autumn of $20 \mathrm{II}$, but prior to reburial an osteological analysis was performed, the find was dated, and samples were taken for various isotope analyses. At the time of writing, the results of all the analyses have not yet come in. I am well aware that the skeleton is probably lost to us when it comes to further research, but in my opinion we made the right decision. The reburial has great significance for the Sami community, both emotionally and symbolically. It also clearly marks the fact that archaeological research is conducted in a completely different way today compared to how it was done not only a hundred years ago but also twenty-five years ago. Words like "involvement" and "influence" should not just be seen as empty talk.

The reburial also provided an opportunity for analyses and plans for continued research within Sami history in the geographical area in question. Everyone involved was fascinated by the chance to participate in the process and write the history of an area where it is more or less unknown. In addition, the reburial is important for the interest it can generate in early Sami history. Since the early I980s, Jamtli has been clearly oriented to conducting research and documentation of early Sami history both on its own and together with other institutions. A significant part of this work, of course, involves the spread of information, a process in which the mass media plays an important role. However, it is not self-evident that the results obtained by modern research will be accepted by the non-Sami community. In actuality the climate for discussion has become more difficult in the last ten years. The possibility that few people will contest the idea that the Sami have a history in Sweden is not necessarily a comfort. If there is continual criticism and mockery of research results, and it becomes part of media hype, there is a risk that it will become an everyday phenomenon which then can be used in a general mistrust of the experts. That this is a reality for those of us engaged in writing Sami history is shown by the example below.

At the same time as preparations were made for the reburial - which occasionally brought intensive coverage from the media - we at Jamtli held an exhibition on the Viking Age. In the same year, 2010, the political party the Sweden Democrats won their first-ever seats in Swedish parliament. The party's main platform is the Swedish immigration policy, which, in their opinion, is much too lenient and generous. Immigrants are seen negatively in relation to pensions, health care, schools, and employment opportunities, and they are given the blame for a large part of the Swedish crime rate. Islamophobia is a constant presence in the argumentations of the Sweden Democrats. A cornerstone in the Sweden Democrats' reasoning is that immigrants do not have Swedish values and they belong to another culture. They have their roots in a different 
history than the alleged original Swedish one. That the Sweden Democrats' view of history is both one-dimensional and unproblematized can hardly be doubted. To take hold of the Swedish history and define what is Swedish is an intentional strategy designed to distinguish us (Swedes) from them (immigrants).

Naturally, this has given rise to much reaction. Many critics have launched counterattacks in order to show the absurdity of the Sweden Democrats' view of history. In an archaeological context, reference can be made to Björn Magnusson Staaf, the chairman of the Swedish Archaeological Society, who in a newspaper article pointed to the dangers of not making archaeological research public and not telling people where it stands today (Magnusson Staff 20IO).

The Sweden Democrat Party's definition of immigrants and Swedes, as well as their view that one can distinguish and use as evidence differences that have their roots in history, has, however, a completely different relevance in the northern half of Sweden. The reasoning is in principle the same but the target group is different. Here it is the Sami who are under fire. The exhibition we had at Jamtli in 20I0 was a theme project on the Viking Age with special focus on textiles of the time period. In the catalogue for the exhibition, I wrote among other things a brief account of the Viking Age and I described what a Viking is. In one paragraph I noted that most Vikings were not engaged in trade journeys and Viking expeditions, but rather most of them were busy with other activities, regardless of whether they lived in a longhouse or a kàta, a Sami hut. To say there were people living in kåta huts a thousand years ago in Jämtland and Härjedalen is not a remarkable statement to make today. It is not my intention to simplify in any way the discussion of Sami ethnicity in early history, but to say that there are traces of a Sami population from the Viking Age in Jämtland and Härjedalen is not controversial. (For anyone wishing to learn more about the discussion, I recommend Stig Welinder's book Jämtarna och samerna kom först, from 2008.) Reaction to the statement I made in the catalogue appeared immediately, however, among the Letters to the Editor in the local newspaper.

One writer in particular stood out in the debate that ensued. By referring to literature from the early twentieth century and to church registers etc., the writer claimed that Jamtli lies and creates false histories. It was also said that Jamtli, together with reindeer herders, had for I4 years tried to create evidence for Sami presence in the county, but that Sami were not present in Härjedalen before I76I, or in any case they were not present in the county before 1650 (Hermansson 20I0). That some individuals for various reasons do not want to believe that the Sami have a long history in Jämtland County is simply how things are. But the trou- 
bling thing in this case, and what breaks the pattern, is that the writer signed himself as Lars Hermansson, Sweden Democrats. Hermansson is a politician, elected by the people, and serves as a group leader for the Sweden Democrats in the municipal assembly in Härjedalen Municipality. The opinions he expresses are those of the party. The background to Hermansson's discussion in the newspaper is his view that reindeerherding Sami have unfair privileges in relation to the rest of the population in Härjedalen. Ongoing disputes over the right to winter grazing grounds for reindeer, as well as the reparations for private properties taken by the State in mountainous areas at the end of the nineteenth century to secure the presence of grazing grounds, are underlying reasons for his involvement. In light of this it is understandable that a modern account of history is not welcome. The older notion that the Sami are relatively late immigrants is much more suitable if the purpose is to show that the Sami do not have the right to grazing grounds. The local Sweden Democrats make use of history and archaeology in the same way as the party does on the State level. By putting out a simplified view of culture, history and identity, one that gives the Sami a non-existent history in Jämtland, the Sweden Democrats can argue that the Samis' rights as an original people rest on false premises.

More aspects of Hermansson's rhetoric can be examined on his blog (http://larshermansson.blogspot.com/), where he goes to attack against Jamtli - once again calling it corrupt - as well as researchers, reindeer herders, and members of parliament.

The choice of words is unforgiving: "Jämtland's county museum is corrupt", "Jämtland's museum is only good to laugh at", "He [Ove Hemmendorff, Jamtli, my remark] did not want the support for reindeer husbandry to be known" (Hermansson 20I00II2). "Reindeer abuse and Lapp devils" (Ibid 20080326). "They're supported by silly celebrities with no knowledge of Norrland" (Ibid 20080220). "Stop the liar, the Lapp Olof T. Johansson's lies, the lies of the Lapps" (Ibid 20080627). "The reindeer-herding Lapps make fools of themselves" (Ibid 20090219). "Damn the stupid Norrlandic parliament members of the last hundred years who let reindeer-herders expand and terrorise other Norrlanders!" (Ibid 2008072I).

In the blog there are references and statements to show that the Sami do not have a long history in the area. The source used most often is the book Härjedalens ortnamn och bygdesägner, published in I9I I and written by Erik Modin, a researcher and priest. Modin was a typical researcher of local ethnology during his time, and he has many merits. However, his conclusions and interpretations concerning Sami history are no longer feasible, which is hardly surprising. After all, most of Mo- 
din's work was done over a hundred years ago. Paradoxically, it is the very fact that his research is old that makes it, in Hermansson's view, more truthful than research of today.

Of essence in the context of Hermansson, however, is that it is not about a private individual. No one can take away Hermansson's right to write his own history. Of essence is that he represents a party with seats in parliament in Sweden today. When publicly elected politicians write an official history to justify their standpoints, things are pretty bad.

My example is taken from the south Sami area, but it describes part of daily life within archaeology for me and many of my colleagues in northern Sweden. That is, it is not uncommon to be accused by local politicians and others of being a liar, of being corrupt and bought by those pursuing reindeer husbandry. What, then, is the best way to deal with the situation? First and foremost by taking the situation seriously and being prepared for discussion. I do not think I can convince those who, for some reason, need their own account of history. On the other hand, I can influence others who are not necessarily as emotionally involved in the issue of reindeer grazing grounds. When the Sweden Democrats continually spread their own version of history and the ones who do it are public persons (politicians), it is inevitable that people in general will adopt parts of the history and make it their own. This can only be counteracted by tireless efforts to put the spotlight on the results of modern research. It is important to take every opportunity to tell people where research stands today. If any unpleasantness occurs, one simply has to take it in stride. Archaeology has never been, and never will be, value neutral. This is something we have learned from history. It is from this perspective, among others, that we should view the discussion on repatriation and reburial of Sami remains. Reburial is not an act devoid of symbolism. Its importance for the recognition of Sami history and the Sami people cannot be exaggerated. In addition, the reburial that took place in autumn 20 I I will in my view lead to more research with greater involvement by the Sami than earlier.

Anders Hansson, Jamtli

\section{References}

Hermansson, L. 20I0. Jamtli förfalskar vikingatiden och samernas historia. Östersundsposten 20100722. P. 10.

Hermansson L. (20100II2), (2080326), (20080220), (2009002 I9), (2008072I). (Blog). http://larshermansson.blogspot.com/ (Accessed 20II-05-05). 
Magnusson Staaf, B. 20I0. Kontroll över kulturarvet SD:s medel för att nå makt. http:// www.dn.se/debatt/kontroll-over-kulturarvet-sds-medel-for-att-na-makt (Accessed 20II-05-05).

Sundström, J. 1988. Graven vid Gransjön i Frostviken. Åarjel-saemieh, Samer i sør, årbok. 3. Pp I36-I 44. Snåsa.

Welinder, S. 2008. Jämtarna och samerna kom först. Östersund: Jamtli förlag. 